\title{
Economic Analysis of the Hook and Line Fishery in Kombuthurai Coast, Tamil Nadu
}

\author{
KALIDOSS RADHAKRISHNAN"1, MUTHUPANDI KALAIARASAN², \\ M.S. MADAN ${ }^{1}$, P.N.ANANTH ${ }^{3}$, T. UMAMAHESWARI ${ }^{4}$ and R VELMURUGAN ${ }^{4}$
}

${ }^{1}$ Central Marine Fisheries Research Institute, Thoothukudi - 628002, India. ${ }^{2}$ Fisheries College and Research Institute, Ponneri, Thiruvallur - 601204 , India. ${ }^{3}$ Krishi Vigyan Kendra - Khordha, Central Institute of Freshwater Aquaculture, Bhubaneswar - 751 002, India.

${ }^{4}$ Fisheries College and Research Institute, Thoothukudi, India.

http://dx.doi.org/10.12944/CWE.11.3.28

(Received: March 05, 2016; Accepted: November 29, 2016)

\begin{abstract}
The present investigation is about the economic analysis of the hook and line fishery along the coast of Kombuthurai, Thoothukudi district of Tamil Nadu. Inferences from the study indicated that that hook number 5, 6 and 7 were found ideal for commercial exploitation of Carangids, Grouper, Barracuda and Needlefish in angling by wielding fresh condition live bait. Using the artificial lure number 3.5, 4.0 and 4.5 used in trolling line, the most dominant catch was seer fish $(80 \%)$ and least in sailfish (8\%). Significantly the study reports that the highest gross revenue ₹ 42060/trip was made in trolling line than that of the handline of ₹ $26400 /$ trip ascribed by targeted high market value species. The trolling line crew share per person was twice over than the handline fishing ( $₹ 3821 /$ trip). Instead of unorthodox eye estimation of fish weight, a novel approach of weight based fish sale (for low to high market value species) was observed in Kombuthurai fishing village and this practice also espoused by a neighbor fishing village.
\end{abstract}

Keywords: Troll line, handline, live bait, artificial lure, market, open auction.

\section{INTRODUCTION}

Marine fishers use different type of crafts (boats) and gears (nets) for harvesting fish and its efficiency is significantly important for better income. Hook and line is a traditional gear which habitually operating in the motorized and mechanized vessels due to nature of the gear such as simple for construction, easy to operate and selective in nature ${ }^{4}$. In the recent years, the practices of hook and line are fascinating amid fishers; it excels in capturing high market value species namely the seer fish, mackerel, tuna, elasmobranchs etc. ${ }^{4,26,27}$. With worthiness, the hook and line were deemed as important, so studies on their performances were done for better understanding ${ }^{5,20,11,27}$. The hook and lines contribute about $2 \%$ of the total marine fish landing of India and the share of mechanized hook and lines are with 0.05 lakh tonnes and outboard hook and lines tunes to 0.59 lakhs tonnes ${ }^{25}$. Among hook and line, the handline, pole and line, trolling line, jigging line and longline are prominent which are in practice throughout coastal region of India. It was recognized as eco-friendly fishing gear than other kinds of fishing practices but it also catches the non-target species ${ }^{3,19,17,7}$. It is also interesting to note that they perform even in the rocky area and uneven bottom places as well ${ }^{10}$.

Bait is the key factor in line fishing, which depend on the foraging behaviour of fish 12,10 , stimulants, and sensory modalities ${ }^{14,16}$. The 
taste, texture, and size of the feed also important deemed which encourage the fish to approach the feed. The environmental parameters including light, temperature, current and prey density also affect the feeding behavior ${ }^{16}$. Low value fishes like sardine, and squid however are also used for human consumption and considerably the price of bait has also increased over a period of time. Hence, it is important to identify alternative bait which ought to be efficient, accessible, easy to operate with high catch efficiency, long life, and low cost. Research and Development initiatives have focused on developing artificial baits, and similar, however, a phosphorescent plastic bait was developed during $1960-1970^{22}$. A modern fish lure was developed by Heddon and Pflueger in Michigan during the early 1900s. Despite, many further development studies were also carried out throughout the world in these aspects ${ }^{13,15}$. It is observed that using lure and fresh conditioned bait has become common in fishing and also gaining importance especially in the study area viz., Thoothukudi coastal region of Tamilnadu due to higher catch efficiency and lower operating cost. The idea behind this investigation is to understand the economics analysis of handline with live bait and trolling with artificial fish light lure practiced by the fishermen. The study also targeted to document the gear description and operation details.

\section{MATERIALS AND METHODS}

The present study was conducted at Kombuthurai fish landing centre (Lat. $8^{\circ} 34^{\prime} 50.49 "$ $\mathrm{N}$ and Long. $\left.78^{\circ} 08^{\prime} 12.91^{\prime \prime} \mathrm{E}\right)$ during the period September 2014 to May 2015. For the present study an experimental fishing was conducted on handline (Fig. 1) and trolling line (Fig.2); for which their general descriptions are presented in Table 1. The mainline and branch lines were made of nylon monofilament. With three different hooke sizes of ' $J$ ' type viz. hook no. 5,6 and 7 in hand line and three different sizes of artificial lures viz. 3.5, 4.0 and 4.5 in trolling lines were found to be used by the fishermen. A light was placed to inside the lure to attract the fish and it lightene when it shakes. To elicit the economic analysis of hand and trolling lines the primary data was collected from all the handliners (20) and trolling lines (15) the Kombuthurai landing centre, Thoothukudi district, Tamil Nadu using a pre- tested interview schedule. Data pertaining to details of fishing gears especially the design and operation catch details, price and other relevant information were also collected for the study. The secondary data on gear operations and number of fishermen using different crafts and gears were collected from the State Fisheries Department, Government of Tamil Nadu. For this study, the cost of production was grouped into two categories as fixed and operating costs and cost for deriving results on the economic analysis. Formulae used for the calculation are as indicated.

Net return $=$ Gross revenue - Total cost Gross revenue $=$ price of fish $/ \mathrm{kg}$ (₹) $X$ quantity of fish caught on that day

Total cost $=$ Total Fixed Cost (TFC) + Total Variable Cost (TVC)

TFC is the sum of fixed cost and TVC is the sum of variable cost.

The results are presented in the tabular and graphical form. The entire data analysis was thru in Microsoft Office, 2016 in windows 8.0 version.

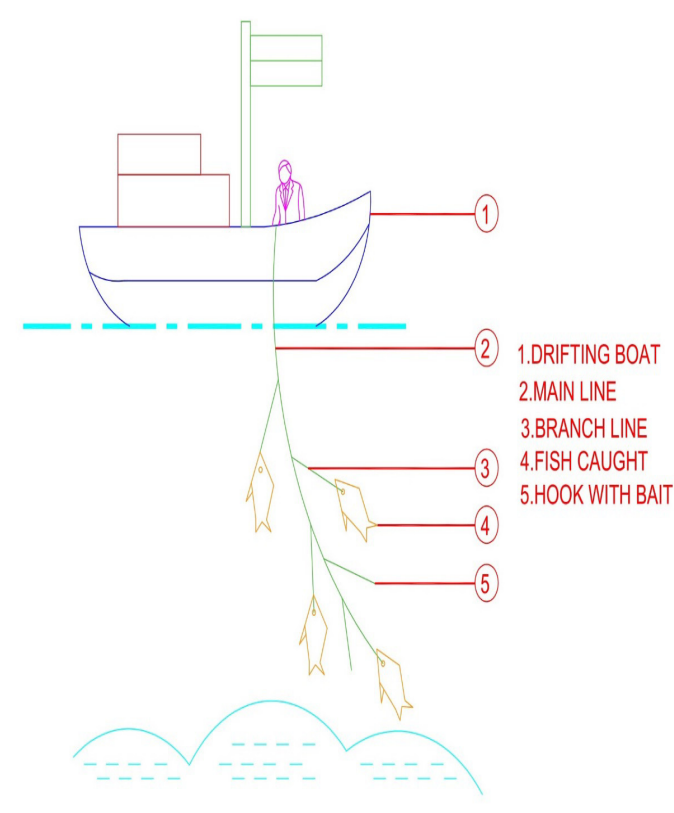

Fig.1: Traditional Handline 


\section{RESULTS AND DISCUSSION}

\section{Operational details}

The experimental handline and trolling line were operated by $15 \mathrm{~m}$ (OAL) FRP boat each fitted with 9.9 Hp Out Board Motor (OBM) (Table 2). The towing speed about 5 to 6 knots while fishing and running speed about $10 \mathrm{kw} / \mathrm{hrs}$. The number of the crew for trolling and handline was found to be 3 and 4 persons / boat respectively. The handline was operated (Fig 1) during October to March of every year. But, a study stated that the handline was operated around the year and peak season lie during January to March ${ }^{18}$. Handline of 3 to $20 \mathrm{~m}$ length and 1 to 20 hooks were used in Nicobar 1 . The float was attached for the easy identification of the line. The distance between each line was about 10 to 12 feet to cover a wide area and avoid the escape of fishes. The bait varied with fishing methods as well as target species. In addition, the prawn, sardine, anchovies and squid were the prominent baits employed in handline and trolling line ${ }^{2}$. Another study in Nicobar, found that the fish (sardine, anchovies, and carangids), hermit crab and filamentous algae were used as live baits in handline, trolling line and longline ${ }^{1,21}$. However, a better catch efficiency was recorded by using the fresh condition live bait rather than natural bait in dead condition at Kombuthurai.

Table 1: General description of the Trolling line and Handline in Kombuthurai coast

\begin{tabular}{clll}
\hline $\begin{array}{l}\text { S. } \\
\text { no }\end{array}$ & Name of the items & $\begin{array}{l}\text { Trolling line with } \\
\text { artificial lure }\end{array}$ & $\begin{array}{l}\text { Handline with } \\
\text { Natural bait }\end{array}$ \\
\hline 1. & Length of mainline $(\mathrm{m})$ & 25 & $25-30$ \\
2. & Height of branch line $(\mathrm{m})$ & - & 0.5 \\
3. & Height between the branch line $(\mathrm{m})$ & - & 0.5 \\
4. & Hook/Lure number & $3.5,4.0$ and 4.5 & 5,6 and 7 \\
5. & Bait type & Artificial lure & Live and natural bait \\
6. & Depth of operation $(\mathrm{m})$ & 20 & $25-30$ \\
7. & Material used for mainline & Monofilament (Nylon) & Monofilament (Nylon) \\
8. & Diameter of mainline $(\mathrm{mm})$ & 1.5 & 1.3 \\
9. & Material used for branch line & Monofilament (Nylon) & Monofilament (Nylon) \\
10. & Diameter of branch line $(\mathrm{mm})$ & - & 1.1 \\
\hline
\end{tabular}

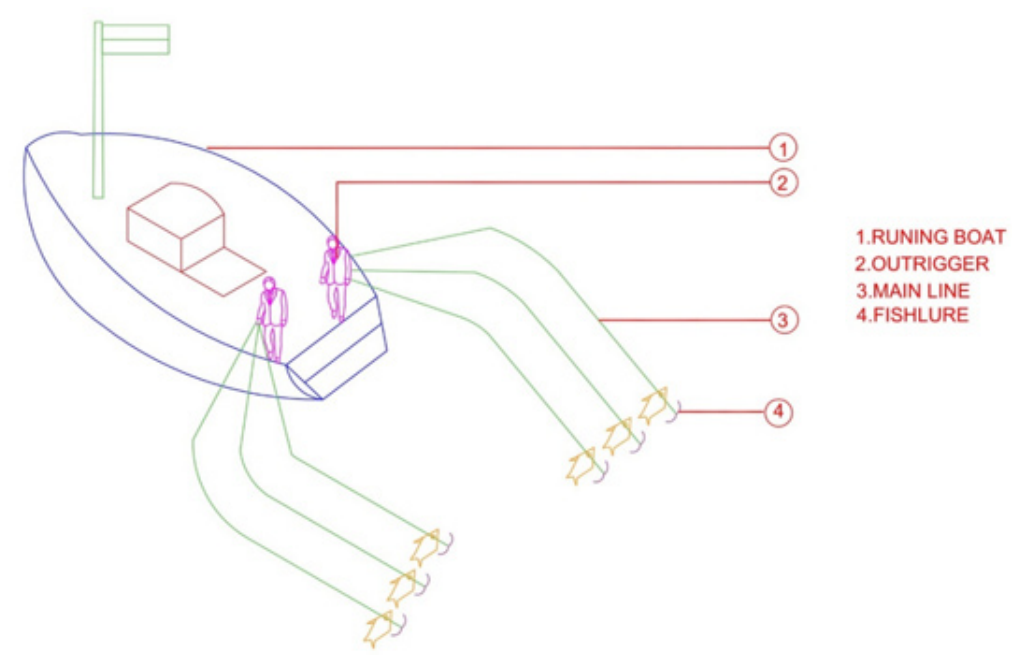

Fig. 2: Traditional Trolling Line 
Similarly, the fresh condition baits were also utilized to capture the carnivore fishes in Nicobar ${ }^{21}$.

The trolling line with lure operated (Fig 2) during the southwest monsoon season i.e from the month of May to September and jigging in June and July is in accordance with the earlier reports ${ }^{18}$. The bright colour lure (red and black) was used during water turbid periods and the dull colour lure during clear water periods. The low cost lure (₹ 120) was utilized for about 5 to 6 fishing operation and the high-cost lure ( $₹ 500$ ) 15 to 20 fishing operation. However, for a single operation, 20 to 25 lure were employed. The double hook lure performed for better catch efficiency and distance between the trolling line was about 1.0 to $2.0 \mathrm{~m}$. The branch line length was uneven to avoid the fish from escapement. Locally made artificial baits were used in Nicobar using broiler chicken feather, plastic waste, rubber waste, nylon rope, nylon twine and fish lure ${ }^{21}$.

\section{Species Composition}

The computed catch rate of the handline and trolling line is presented in figure 3 and 4 respectively. The larger size Grouper landing

Table 2: Operational and techno-economic characteristics of the Trolling line and Handline in Kombuthurai coast

\begin{tabular}{clcc}
\hline $\begin{array}{l}\text { S. } \\
\text { no }\end{array}$ & Name of the items & $\begin{array}{c}\text { Trolling line with } \\
\text { artificial lure }\end{array}$ & $\begin{array}{c}\text { Handline with } \\
\text { Natural bait }\end{array}$ \\
\hline 1. & Type of fishing boat & FRP & FRP \\
2. & Length of the fishing boat (M) & 15 & 15 \\
3. & KW/ hr. & 10 & 10 \\
4. & On board facilities & No & No \\
5. & Fuel (litre/trip) & $75-85$ & $120-130$ \\
6. & Number of crew & 3 & 4 \\
7. & Number of shares & 5 & 6 \\
8. & Gear expenses (₹) & $650 /$ piece & $3000 /$ roll \\
9. & Other running cost (₹) & 150 & 150 \\
10. & Ownership & Single & Single \\
11. & Fishing days (days per annum) & $52-60$ & $113-120$ \\
12. & Horse Power of the engine (hp) & 9.9 & 9.9 \\
\hline
\end{tabular}

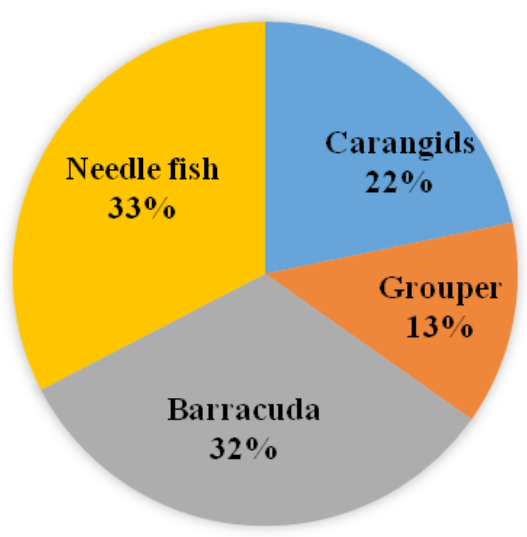

Fig. 3: Species composition of major food fishes by handline fishing with live bait

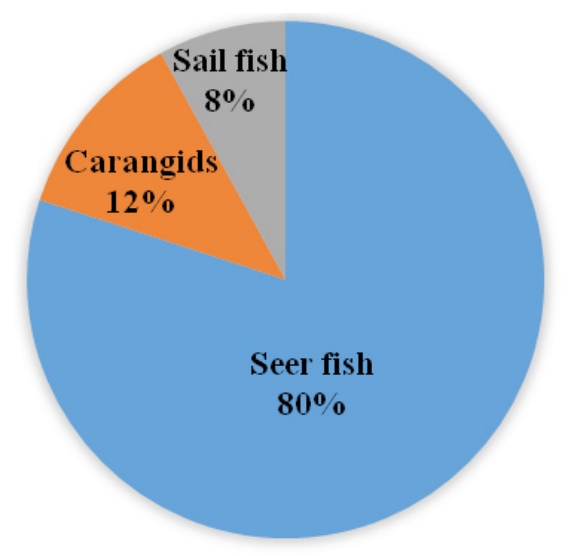

Fig. 4: Species composition of major food fishes by trolling line fishing with artificial lure 
was accounted in hook no. 5 and minimum in 7 of handline. Similarly larger size of Seer fish, was recorded in lure size no. 4.5 and least in 3.5 in trolling line. Needlefish was the most dominant group of finfish $(33 \%)$ and least dominant catch was Groupers (8\%) in the handline fishery (Fig 3). But, in a trolling line the dominant group of finfish was Seer fish (80\%) followed by Carangids (12\%) and Sailfish (8\%) (Fig 4). At Thoothukudi Threadfin
(30\%) was the prominent landing species in handline followed by $20 \%$ of lethrinids, $19 \%$ of Belone spp., $10 \%$ of serranids, and $6 \%$ of carangids ${ }^{23}$. An attempt was aslo taken to study the species composition in trolling line operation of which Mackerel, queenfish, Caranx sp. (carangids), herring, cobia, and tuna were the major fish catches ${ }^{6}$. Mackerel landing was highest than followed by queen fishes and caranx. The average catch per day ranged from 21.2 to 116.5

Table 3: Gross Income of the handline

\begin{tabular}{clccc}
\hline $\begin{array}{l}\text { S. } \\
\text { No }\end{array}$ & Name of fish & $\begin{array}{c}\text { Total fish } \\
\text { landing (kg) }\end{array}$ & $\begin{array}{c}\text { Price / kg } \\
\text { (₹) }\end{array}$ & $\begin{array}{c}\text { Gross } \\
\text { Income (₹) }\end{array}$ \\
\hline 1. & Carangids & 150 & 130 & 19500 \\
2. & Grouper & 12 & 150 & 1800 \\
3. & Barracuda & 30 & 70 & 2100 \\
4. & Needlefish & 30 & 100 & 3000 \\
& Total & & & 26400 \\
\hline
\end{tabular}

Table 4: Gross Income of trolling line

\begin{tabular}{|c|c|c|c|c|}
\hline $\begin{array}{l}\text { S } \\
\text { No }\end{array}$ & Name of fish & $\begin{array}{c}\text { Total fish } \\
\text { landing }(\mathbf{k g})\end{array}$ & $\begin{array}{l}\text { Price / kg } \\
\text { (₹) }\end{array}$ & $\begin{array}{c}\text { Gross } \\
\text { Income (₹) }\end{array}$ \\
\hline 1. & Seer fish & 80 & 500 & 40000 \\
\hline 2. & Carangids & 15 & 130 & 1950 \\
\hline 3. & Sailfish & 1 & 110 & 110 \\
\hline 4. & Total Income & & 42060 & \\
\hline \multicolumn{5}{|c|}{$\begin{array}{l}\text { Table 5: Cost and returns of handline } \\
\text { and trolling line fishing ( } ₹ / \text { trip) }\end{array}$} \\
\hline $\begin{array}{l}\text { S. } \\
\text { No }\end{array}$ & \multicolumn{2}{|c|}{ Name of particulars } & \multirow[t]{2}{*}{$\begin{array}{l}\text { Hand line } \\
\text { fishing }\end{array}$} & $\begin{array}{l}\text { Trolling line } \\
\text { fishing }\end{array}$ \\
\hline \multirow[t]{6}{*}{1.} & \multicolumn{2}{|c|}{ Total variable cost } & & \\
\hline & \multicolumn{2}{|l|}{ Fuel } & 3125 & 2000 \\
\hline & \multicolumn{2}{|l|}{ Ice } & 50 & 50 \\
\hline & \multicolumn{2}{|l|}{ Food } & 150 & 0 \\
\hline & \multicolumn{2}{|c|}{ Other operating cost } & 150 & 150 \\
\hline & \multicolumn{2}{|l|}{ Total } & 3475 & 2200 \\
\hline 2. & \multicolumn{2}{|c|}{ Gross revenue } & 26400 & 42060 \\
\hline 3. & \multicolumn{2}{|c|}{ Net return (without fixed cost) } & 22925 & 39860 \\
\hline 4. & \multicolumn{2}{|c|}{ Number of shares } & 6 & 5 \\
\hline 5. & \multicolumn{2}{|c|}{ Share per crew } & 3821 & 7972 \\
\hline 6. & \multicolumn{2}{|c|}{ Owners share } & 7642 & 15944 \\
\hline
\end{tabular}


$\mathrm{kg}$. Seerfish, tuna, barracuda, caranx and mackerel landings were observed in trolling line using the artificial and natural bait ${ }^{1}$.

\section{Economics}

It is a fact that the technical features of the fishing vessels influence the fish catch ${ }^{8,9}$. This study also attempted in these lines to obtain data on better utilization and optimum substitution of the input variables.

The gross income for handline (Table 3 ) and trolling line (Table 4) was calculated and a sum of $₹ 26400$ and $₹ 42060$ was earned respectively which also depends on the quantity of landings and price of the fish. It was observed that $222 \mathrm{~kg}$ of fish was landed through handline and $96 \mathrm{~kg}$ in trolling line. The species selectivity also affects the fishing strategies and distribution (horizontal and vertical) of fish. The area and depth of operation is normally based on the experiences of the skipper and fish detecting devices also the catch rate improve with increased depth of operation. However, the price per kg realized was found to be higher for seer fish than those of other species; a similar kind of report was inferred in another study ${ }^{24}$. The price variation depends upon the supply and price of the related species landing. The price of fish is highly elastic compared to the agriculture commodities due to the nature of perishability and uncertainty in landings. The market timing yet another factor affects the price ${ }^{24}$.

The calculated cost and returns details was depicted Table 5. The economic returns were found to be higher in trolling with a return of ₹ 39860 than that of the handline fishing ₹ 22925 excluding the fixed cost and the crew share was about $₹ 7972$ and ₹ 3821 respectively. In addition, the owners have two shares for the craft and engine. The owner share (earning) was twofold higher in trolling line than the handline fishery which means the trolling line vessel owner earned an income of ₹ 15944 and the handline vessel owner with ₹ 7642 .

\section{Market structure}

In India, the domestic fish marketing system is carried out by the private dealers between producer and consumer ${ }^{8}$. An auctioneer is a middle man in marine fish marketing who auctions the fishes provides by fisherman to various stakeholders. The auctioneer offers advance money to fishermen to take the rights of the auction of his catches, and also charged $5 \%$ of the total sales as auction fee. The fishes sale is being practiced by open auction for a heap of fish in all marine fish landing centre of India ${ }^{24,26}$ and there is no exception for Tamil Nadu. But controversial to this existing practice, fish sales is done through open auction based on price per $\mathrm{kg}$ weight. In the study area and the same is also accepted by a nearby village Amalinagar as they believe that by adopting this method underestimation of fish price could be curtailed. The result would definitely paves an easy way to estimate production at the individual level to draw policy conclusions and to initiate development interventions.

\section{CONCLUSION}

In the present study, an attempt has been made to evaluate the income of the handline and trolling line fishery at Kombuthurai, Tamil Nadu. The trolling line fishermen had higher gross income (142060/trip) as compared to handline fishers (126400/trip). The greater income was achieved by target fishing and high market value species through adoption of novel marketing practiced by them, which is open auction based on price per $\mathrm{kg}$ weight method. In upcoming smarketing studies, this efficcent method should be focused on the practice of line fishery, help us to compute the stock status, potential catch and bycatch reduction. So, upcoming policies should give importance to the hook and line fishery to secure the juveniles and sustainable fisheries.

\section{ACKNOWLEDGEMENTS}

The author would like to thank the Research Centre of Central Marine Fisheries Research Institute, Thoothukudi for providing facilities for undertaking this study. Authors also thankful to Mr. Muthukumar for his artwork. 


\section{REFERENCES}

1. Ahmed, S.Z., Ravikumar, T., Krishnan, P. and Jeyakumar, S. Traditional fishing crafts and gears used by the Nicobari tribes in Car Nicobar. Indian Journal of Traditional Knowledge, 12(1): 144-148 (2013).

2. Balasubramanyan, R. On the use of different natural baits for sea-fishing in India. Fishery technology, 1(1): 41 - 47 (1964).

3. Belda, E.J. and Sanchez, A. Seabird mortality on longline fisheries in the western Mediterranean: factors affecting bycatch and proposed mitigating measures. Biological Conservation, 98(3): 357-363 (2001)

4. Bjarnason, B. A. Handlining and squid jigging. Food and Agriculture Organization of the United Nations Rome, (1992)

5. Bjordal, Å. Effect of different long-line baits (mackerel, squid) on catch rates and selectivity for tusk and ling. ICES.(1983)

6. Dhawan, R.M., Namboothiri, P.V.S. and Gopinathan, V.G. Results of trolling line operations in Goa waters during 1965-68. Indian Journal of Fisheries, 16(1\&2): 181-187 (1969)

7. Diaz, G.A. The effect of circle hooks and straight $(\mathrm{J})$ hooks on the catch rates and numbers of white marlin and blue marlin released alive by the US pelagic longline fleet in the Gulf of Mexico. North American Journal of Fisheries Management, 28(2): 500-506. 2008

8. FAO. Techno-economic performance of marine capture fisheries. Fisheries technical paper No. 421. Food and Agriculture Organization of the United Nations Rome. (2001)

9. FAO. Economic performance and fishing efficiency of marine capture fisheries. Fisheries technical paper No. 482. Food and Agriculture Organization of the United Nations Rome (2005)

10. Hameed and Boopendranath, 2000 Modern fishing gear technology. Daya Publishing house, Delhi, $186 \mathrm{p}$.

11. Lewison, R.L., Freeman, S.A. and Crowder, L.B. Quantifying the effects of fisheries on threatened species: the impact of pelagic longlines on loggerhead and leatherback sea turtles. Ecology letters, 7(3): 221-231
(2004)

12. Løkkeborg, S. Longline bait: Fish behaviour and the influence of attractant release rate and bait appearance. Dr. scient. thesis. Department of Fisheries Biology University of Bergen. Bergen, 1989, 9-27 (1989)

13. Løkkeborg, S. Reduced catch of under-sized cod (Gadusmorhua) in Longlining by using artificial bait. Canadian Journal of Fisheries and Aquatic Sciences 47: 112-1115 (1990).

14. Løkkeborg, S., and Bjordal, Å. Species and size selectivity in longline fishing: a review. Fisheries Research, 13(3): 311-322 (1992)

15. Løkkeborg, S. andJohannessen, T. The importance of chemical stimuli in bait fishingfishing trials with presoaked bait. Fisheries research, 14(1): 21-29 (1992).

16. Løkkeborg, S., Siikavuopio, S.I., Humborstad, O.B., Utne-Palm, A.C. and Ferter, K. Towards more efficient longline fisheries: fish feeding behaviour, bait characteristics and development of alternative baits. Reviews in Fish Biology and Fisheries, 24(4): 985-1003 (2014).

17. Kumar, K.A., Khanolkar, P.S., Pravin, P., Madhu, V.R. and Meenakumari, B. Effect of hook design on longline catches in Lakshadweep Sea, India. Indian Journal of Fisheries, 60(1): 21-27 (2013).

18. Mathew, G. and Venugopal, K.M. Hooks and line fishery for 'Kalava' at Cochin. Indian Journal of Fisheries, 37(4): 347-355 (1990).

19. Polovina, J.J., Howell, E., Parker, D.M. and Balazs, G.H. Dive-depth distribution of loggerhead (Carrettacarretta) and olive ridley (Lepidochelysolivacea) sea turtles in the Central North Pacific: Might deep longline sets catch fewer turtles? Fishery Bulletin, 101(1): 189-193 (2003)

20. Ralston, S. Influence of hook size in the Hawaiian deep-sea handline fishery. Canadian journal of fisheries and aquatic sciences 39: 1297-1302 (1982).

21. Ravikumar, T., Ram, N., Krishnan, P., Sankar, R.K., Sachithanandam, V. and Roy, S.D., 2016. Subsistence fishing methods of Nicobari tribes using traditional knowledge. Journal of Marine and Island Cultures, 5(1): 79-87. 
22. Salómonsdóttir, E. Gervibeita, heimildaleit (Artificial bait, Literature research). The Icelandic Fisheries Laboratories, Reykjavík, Iceland. 1970.

23. Sam Bennet, P. and Arumugam, G. Advancement in traditional fishing methods for nearshore fisheries around Tuticorin, Gulf of Mannar. Journal of the Marine Biological Association of India, 35(1\&2): 105-108. 1993.

24. Sathiadhas, R. and Narayanakumar, R. Price policy and fish marketing system in India. Journal of Biology Education, 11(4): 225-241 (1994)
25. Sathianandan, T.V. Status of Marine Fisheries Resources in India - An Overview. In: ICAR funded Short Course on "ICT -oriented Strategic Extension for Responsible Fisheries Management, 05-25 November, 2013, Kochi.

26. Sreekrishna, Y ýand Shenoy, L. Fishing Gear and Craft Technology. Directorate of Information and Publications of Agriculture, Indian Council of Agricultural Research, (2001)

27. Vipin, P.M., Ravi, R., Pravin, P., Thomas, S.N. and Edwin, L. Longline fishing for high value species off Southern India with special reference to structural and operational changes.Fishery Technology 51: 87 - 92 (2014). 